could lead to the production of a spindle celled melanoma and no doubt the question of malignancy would be closely bound up with these types of differentiation."

\title{
BIBLIOGRAPHY
}

Ellett, E. C. (1939).-Arch. of Ophthal., Vol. XXI, No. 3, p. 497.

Frost, A. D. (1936).-Trans. Amer. Ophthal. Soc., Vol. XXXIV, p. 86.

REESE, A. B. (1947) -Amer. Jl. of Ophthal., Vol. XXX, No 5, p. 37.

Tном PSON, A. H. (1899).-Trans. Ophthal. Soc. U.K., Vol. XIX, p. 19.

VERHOEFF, F. H. (1923).-A rch. of Ophthal., Vol. LII,. No. 2, p 132.

\section{OBSERVATIONS ON EXPERIMENTAL PNEUMO- COCCAL INFECTION OF THE RABBIT'S CORNEA AND ON THEIR TREATMENT WITH' PENICILLIN*}

BY

J. MACASKill and M. Weatherall

EDINBURGH

THE experimental production of infected lesions of the rabbit's cornea by intra-corneal inoculation of suspensions of pneumococci has been described by Ginsberg and Kaufman (1913) and by Robson and Scott $(1943 a, b)$. Cole, Hamilton-Paterson and Sorsby (1945) were unable to confirm the findings of Robson and Scott, although they used the same strain of pneumococcus. This divergence of results has not, as far as we know, been explained (Fraser, Robson, Scott and Scott, 1945 ; Sorsby, 1946). The present paper reports further observations on the lesions produced by intra-corneal inoculation of the same and other strains of pneumococci and on the effect of penicillin administered subconjunctivally on these lesions. It is by now well known that bacteriostatic concentrations of penicillin can be produced in the aqueous and cornea by subconjunctival injection of suitable doses (Andrews, 1947; Leopold and La Motte, 1945 ; Sorsby and Ungar, 1947; Struble and Bellows, 1944; von Sallmann, 1945). The present observations are directed to show whether this route of administration is in fact as well as in expectation therapeutically efficient, and if so, under what conditions.

\section{Methods}

Young rabbits of both sexes weighing 1.0 to $1.8 \mathrm{~kg}$. were used. Intra-corneal injections were performed as described by Robson

\footnotetext{
- From the Department of Pharmacology, University of Edinburgh. Received for publication, September 11, 1948.
} 
and Scott (1943a) under intravenous thiopentone anaesthesia (approximately $25 \mathrm{mg} \cdot / \mathrm{kg}$.) except in one experiment in which intravenous pentobarbitone (approximately $30 \mathrm{mg} \cdot / \mathrm{kg}$.) was used. A twenty-four hours culture of pneumococci in plain broth was used throughout. Treatment was applied at various times as described in the section on results. Subconjunctival injections were made under the bulbar conjunctiva near the limbus, without anaesthesia, as the rabbits tolerated this procedure well. The eyes were observed daily for the first few days and less often later. Pure penicillin, kindly supplied by Mr. Beal, of Imperial Chemical Industries (Pharmaceuticals), Ltd., was used, freshly dissolved in sterile 0.9 per cent. sodium chloride solution. Some control animals were treated with subconjunctival sodium chloride, some with subcutaneous penicillin, and others received no treatment. No appreciable difference was found between the two groups which did not receive penicillin, and they will be considered together.

\section{Results}

(1) Untreated Cases. - The lesions observed have been of variable severity but fairly constant in type. In the most satisfactory experiments, twelve hours after inoculation, little was to be seen except the mark of the needle and some opacity where the bleb of material had been deposited. By twenty-four hours, this area had become oedematous and infiltrated, and the conjunctiva was congested and a muco-purulent discharge was present. In the next day, the infective infiltration of the cornea extended greatly: iritis often appeared and the conjunctival discharge usually increased. Hypopyon commonly appeared on the third or fourth days, and after this time little increase in the reaction took place... After ten days or so in some cases, and less in milder ones, the lesions began to resolve, leaving a corneal scar sometimes just discernible and sometimes up to $5 \mathrm{~mm}$. in diameter.

Lesions which followed this pattern were not always produced (Table I). In all, five strains of pneumococcus were tried, three of type XIX and one each of type III and type XXIII. One of type XIX, the strain used by Robson and Scott, in our hands consistently produced lesions of the type described when used in a dilution of $10^{7}$ organisms per $\mathrm{ml}$. The type III organism in a dilution of $10^{5}$ organisms per $\mathrm{ml}$. produced in eight out of fourteen eyes inoculated at the same time lesions which at thirty-six hours appeared particularly severe, in one eye a moderate lesion, and in five eyes in three rabbits no lesion at all. The other strains in dilutions from $5 \times 10^{4}$ to $10^{9}$ organisms per ml. produced mild 
TABLE I

Results of intracorneal inoculation of various strains of pneumococci

\begin{tabular}{|c|c|c|c|c|c|c|c|}
\hline \multirow{2}{*}{ Organism } & & \multirow{2}{*}{$\begin{array}{l}\text { Strength } \\
\text { of sus- } \\
\text { pension, } \\
\text { orgs/ml. }\end{array}$} & \multirow{2}{*}{$\begin{array}{l}\text { No. of } \\
\text { rabbits }\end{array}$} & \multirow{2}{*}{$\begin{array}{l}\text { No. of } \\
\text { eyes }\end{array}$} & \multicolumn{3}{|c|}{$\begin{array}{l}\text { Mean severity of untreated } \\
\text { lesion }\end{array}$} \\
\hline & & & & & 2nd day & 4th day & 9th day \\
\hline Type III ... & $\cdots$ & $10^{5}$ & 7\{ & $\begin{array}{l}9 \\
5\end{array}$ & $\begin{array}{l}3 \dagger \\
0\end{array}$ & $\begin{array}{l}t \\
0\end{array}$ & $\begin{array}{l}\dagger \\
0\end{array}$ \\
\hline $\begin{array}{c}\text { Type XIX (A) } \\
"\end{array}$ & $\ldots$ & $\begin{array}{l}10^{7} \\
, y\end{array}$ & $\begin{array}{l}2 \\
3\end{array}$ & $\begin{array}{l}4 \\
6\end{array}$ & $\begin{array}{l}2 \\
1 \frac{2}{3}\end{array}$ & $\begin{array}{l}3 \\
2 \frac{1}{2}\end{array}$ & $\begin{array}{l}3 \frac{3}{4} \\
3 \frac{1}{3}\end{array}$ \\
\hline $\begin{array}{c}\text { Type XIX (B) } \\
, "\end{array}$ & $\ldots$ & $\begin{array}{l}5 \times 10^{4} \\
5 \times 10^{6} \\
5 \times 10^{8}\end{array}$ & $\begin{array}{l}1 \\
1 \\
1\end{array}$ & $\begin{array}{l}2 \\
2 \\
2\end{array}$ & $\begin{array}{l}\text { Mild } \\
., \\
,\end{array}$ & $\begin{array}{c}\text { Mild } \\
\quad " \\
",\end{array}$ & $\begin{array}{l}0 \\
0 \\
0\end{array}$ \\
\hline Type XIX (C) & $\ldots$ & $5 \times 10^{5}$ & 2 & 4 & 0 & 0 & 0 \\
\hline $\begin{array}{c}\text { Type XXIII } \\
" .\end{array}$ & $\ldots$ & $\begin{array}{l}10^{6} \\
10^{9}\end{array}$ & \} & $\begin{array}{l}1 \\
1\end{array}$ & $\begin{array}{l}2 \\
2 \frac{1}{2}\end{array}$ & $\begin{array}{l}\frac{3}{4} \\
\frac{3}{4}\end{array}$ & $\begin{array}{l}0 \\
0\end{array}$ \\
\hline $\begin{array}{l}\text { Type III } \\
\text { Type XIX (C) }\end{array}$ & & $\begin{array}{l}10^{6} \\
10^{6}\end{array}$ & \}$\cdot 2^{*}\{$ & $\begin{array}{l}2 \\
2\end{array}$ & $\begin{array}{c}\text { Fatal } \\
, "\end{array}$ & $\begin{array}{c}\text { in } 36 \\
" n\end{array}$ & $\begin{array}{c}\text { hours. } \\
\text { " }\end{array}$ \\
\hline
\end{tabular}

Notes:-(A), (B), (C). Three different strains of type XIX, as described in the text. (A) is the strain previously investigated by Robson \& Scott $(1943 a, b)$ and by Cole, Hamilton-Paterson and Sorsby (1945).

+ Value at 36 hours. Treated thereafter with penicillin (group C of table II).

* Each rabbit injected with type III in one eye and type XIX (C) in the other.

lesions, apparently independent of dose and healing in a few days. The last were too mild to show clear-cut responses to treatment and were not studied further. Therefore, only the original strain of type XIX produced lesions with -sufficient constancy for satisfactory evaluation of therapeutic-procedures: the eyes infected with the type III organism were, however, also treated at a later stage, with results striking enough to deserve mention.

(2) Effects of treatment.-Three groups of experiments were performed. In each group, five to eight rabbits were infected in both eyes at the same time. Some were used as controls, some were treated with penicillin subcutaneously and some subconjunctivally. The selection of animals for different groups was performed by a random process and without regard for the state of the lesion. The schemes of treatment are shown in Table II. 
TABLE II

Schemes of Treatment

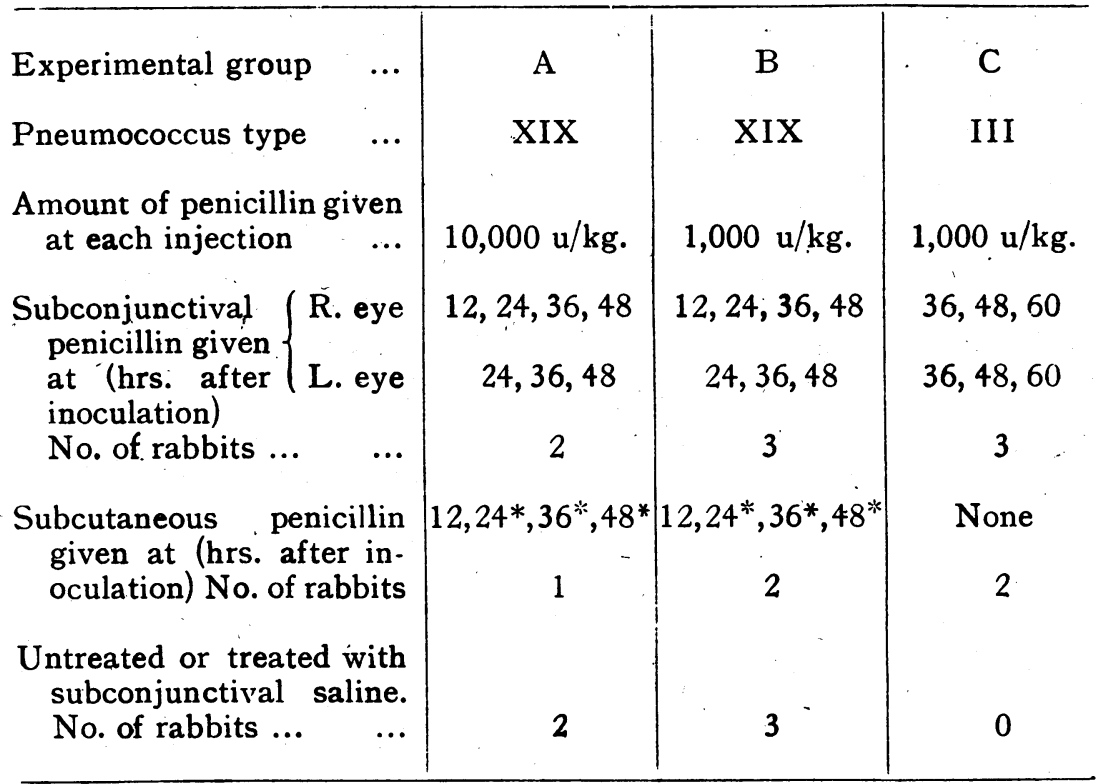

* Double dose, corresponding to the total amount of penicillin given subconjunctivally.

The severity of the lesions observed was scored on an arbitrary scale as follows: The corneal lesion was graded as mild, moderate or severe, and scored 1, 2 or 3 accordingly. Iritis and hypopyon were graded as slight or severe and each scored $\frac{1}{2}$ or 1 accordingly. The total score was summed for each eye. In this way weight was attached mainly to the corneal lesion, but independent cognisance was taken also of the reaction by the deeper parts of the eye. Two observers made independent readings and the average was taken. The mean results for all the eyes on each treatment in each group are shown in Figs. 1-3. .The number of observations is too small to afford an accurate estimate of the variation, but individual values nearly all lay within the range of \pm 50 per cent. of the observed means.

It will be seen that with doses of 10,000 units $/ \mathrm{kg}$. there was little difference in the effects of systemic and local penicillin. Even though the drug was administered as infrequently as twelvehourly, the infection was completely arrested within four days, while the controls were still deteriorating after a week. When the dose used was 1,000 units $/ \mathrm{kg}$. it was practically as effective 
Severity

of lesions

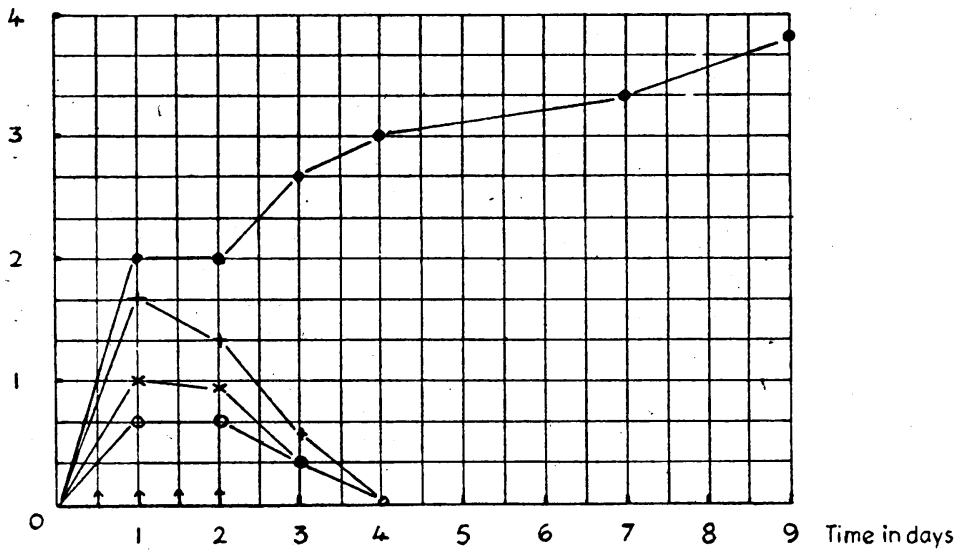

Fig. 1.

Effect of large doses of penicillin on corneal lesions produced by pneumococcus type XIX (experimental group A). Ordinates, severity of lesion in arbitrary units as described in text. Abscissae, time in days from inoculation. Arrows indicate administration of penicillin, 10,000 units $/ \mathrm{kg}$. body weight.

- Solid circles, no penicillin (4 eyes).

$\mathrm{O}-\mathrm{O}$ Open circles, penicillin subcutaneously (2 eyes).

$X-X$ Oblique crosses, penicillin subconjunctivally starting at the first arrow (2 eyes).

+-+ Vertical crosses, penicillin subconjunctivally starting at the second arrow (2 eyes).

Severity

of lesion

4

3

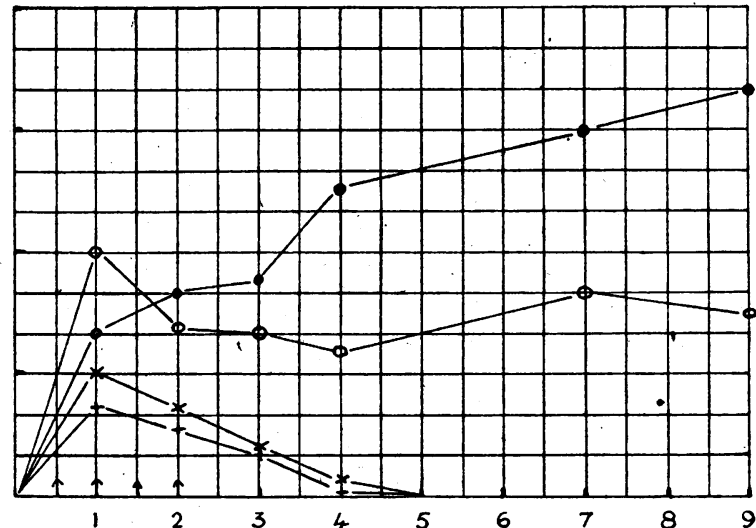

Time in days

FIG. 2.

Effect of small doses of penicillin on corneal lesions produced by pneumococcus type XIX (experimental group B). Ordinates, abscissae and symbols as in Fig. 1. Penicillin 1,000 units/kg. body weight in each dose. Six, four, three and three eyes in respective groups. 


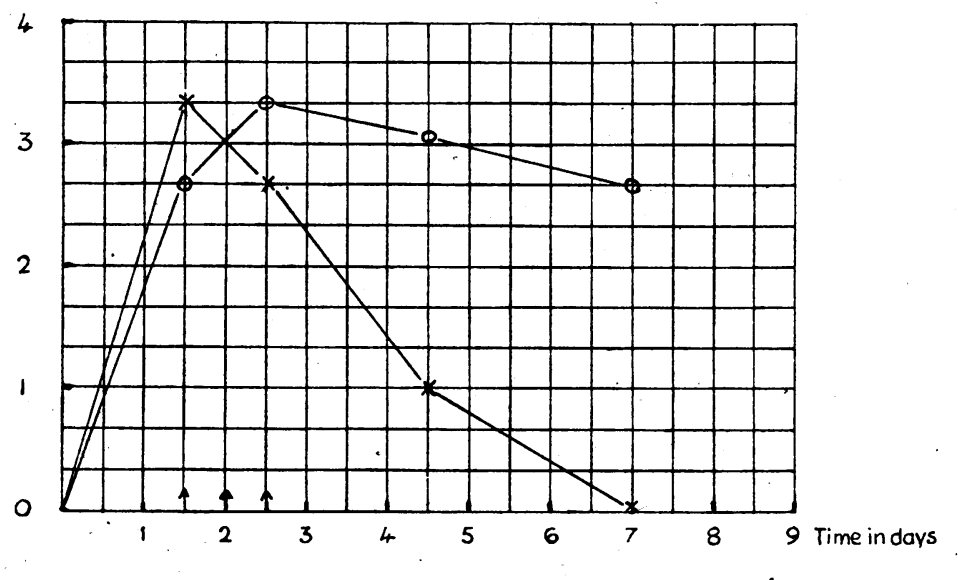

FIG. 3.

Effect of small doses of penicillin on corneal lesions produced by pneumococcus type III (experimental group C). Ordinates, abscissae and symbols as in Fig. 1. Penicillin 1,000 units/kg. body weight in each dose. Six eyes treated subconjunctivally and four subcutaneously.

as the larger dose if given subconjunctivally. Subcutaneously this dose appreciably mitigated the severity of the infection but not unexpectedly was insufficient to produce a cure. This distinction applied equally to treatment started at $12-24$ hours (group B) and when it was delayed until lesions were well established (group C).

\section{Discussion}

Several points of interest arise from these observations. First, the untreated lesions with the type XIX organism used by Robson and Scott and by Cole et al. differ somewhat from those previously reported. On the whole, they resemble those described by Robson and Scott (1943b), but are perhaps better described as infective lesions of the substantia propria of the cornea than as corneal ulcers. Cole et al's (1945) description of their lesion after intra-corneal inoculation of this strain suggests that in their hands a much milder lesion was obtained, probably similar to those reported here with other strains of type XIX and with a strain of type XXIII. There is evidently much variation in the responses produced at different times and by different strains, without obvious reason.

The type XIX lesion has been used in these experiments because in our hands it has been of sufficient constancy and 
duration to show a definite response to treatment, and has allowed discrimination between the efficacy of different methods of treatment. As always, certain differences exist between the experimental lesion in animals and the spontaneous lesion in man; and what is demonstrable for the one is not necessarily true for the other. Nevertheless, until evidence arises to the contrary, the experimental results provide a useful indication of what is likely to occur in man, and with all due caution may be so interpreted.

The data presented leave no doubt that the lesion responds well to treatment with penicillin. The system of dosage used was hardly likely to maintain a bacteriostatic concentration in the cornea and was not intended to do so. Injections at twelve-hourly intervals were used deliberately to see how far adequate results could be obtained with such a clinically preferable long interval between treatments. Zubrod (1947) has recently shown that survival in mice infected with $\beta$-haemolytic streptococci and treated with penicillin $G$ depends mainly on the total dosage and is not increased by giving penicillin more than once in twentyfour hours; and, as Marshall (1948) has pointed out, the assumption that a maintained bacteriostatic concentration is necessary for effective therapy remains unproven. The present experiments are consistent with the hypothesis that it is unnecessary, or at least not altogether necessary.

It is also apparent that subconjunctival administration is substantially more effective than systemic administration, particularly when doses comparable to those used in man are employed. This conclusion is supported by the results one of us (J. M.) has seen in treating septic ulcers of the cornea in man, and by the recently published clinical account by Sorsby and Reed (1947).

\section{Summary}

The responses of rabbits to intra-corneal injections of various strains of pneumococci are described. The lesions were variable, but with one or two strains keratitis, iritis and hypopyon were produced with sufficient constancy to permit the evaluation of therapeutic procedures. Penicillin was found to be more effective when administered subconjunctivally than subcutaneously, and by the former route completely to arrest infection when 1,000 units per kg. body weight was given at twelve-hour intervals.

Acknowledgments. $\mathrm{We}$ are indebted to Dr. J. P. Duguid for much helpful discussion and for providing the cultures of pneumococci; to Dr. J. M. Robson for collaboration in certain 
preliminary experiments; to Miss Irene Munro for technical assistance; to the W. H. Ross Foundation (Scotland) for the Prevention of Blindness for defraying the expenses of this work; and to Imperial Chemical Industries (Pharmaceuticals), Ltd., for a generous gift of pure penicillin.

\title{
REFERENCES
}

ANDREWS, G. W. S. (1947).-Lancet, i, p. 594.

Cole, W. T. S., Hamilton-Paterson, J. L. and Sorsby, A. (1945).-Brit. Jl. Ophthal., Vol. XXIX, p. 150.

Fraser, I. C., Robson, J. M., Scott, A. A. B. and Scott, G. I. (1945).-Brit. Jl. Ophthal., Vol. XXIX, p. 667.

Ginsberg, S. and KaUfman,, M. (1913).-Klin. Monatsbl. f. Augenheilk., Vol. LI, p. 804.

Leopold, I. H. and LAMOTte, W. O. (1945).-Arch. Ophthal., Vol. XXXIII. p. 43.

Marshall, E. K., JR. (1948).-Bull. Johns Hopkins Hosp.. Vol. LXXXII, p. 403.

RoBson, J. M. and ScotT, G. I. (1943a).-Lancet, i, p. 100.

(1943b).-Brit. Ji. Exp. Path., Vol. XXIV, p. 50.

SorsBY, A. (1946).-Brit. Jl. Ophthal., Vol. XXX p. 64

SORSBY, A. and REED, H. (1947).-Brit.Jl. Ophthal., Vol. XXXI, p. 528.

SoRSBY, A. and UNGAR, J. (1947).-Brit. Jl. Ophthal.,, Vol. XXXI, p. 517.

Struble, G. C. and Bellows, J. G. (1944).-Jl. Amer. Med. Assoc., Vol. CXXV, p. 685.

von Sallman N, L.-Arch. Ophthal., Vol. XXXIV, p. 195.

ZuBROD, C. G. (1947).-Bull. Johns Hopkins Hosp., Vol. LXXXI, p. 400.

\section{SCLERAL DEGENERATIONS:- \\ A case of scleromalacia perforans*}

BY

\author{
Dr. S. N. MitteR, \\ DELHI
}

DEgeneration and deficiencies of the sclera have rarely been described in detail. They occur more frequently, but they are not noted as often as would a similar corneal lesion be noted. Rones ${ }^{1}$ in an extensive survey says that senile degenerations in the sclera are chiefly fatty infiltrations. Duke-Elder ${ }^{2}$ states that fatty and hyaline degenerations are fairly common in old age. Calcification is also common as a senile degeneration and as a terminal event in post-inflammatory fibrosis. There is no reason, however, to believe that these degenerations are necessarily limited to old age, as is shown by Coats's case of amyloid degeneration in a man aged 27 years.

Graves $^{3,4,5}$ first described in detail superficial deficiencies of the

- Received for publication, June 28, 1948. 